\title{
Analysis of "E-Patient UNS" Application System for Online Registration of UNS Hospital Patients
}

\author{
$1{ }^{\text {st }}$ Haris Pujianto, $2^{\text {nd }}$ Siti Rokhmah \\ ${ }^{1,2}$ Institut Teknologi Bisnis AAS Indonesia Surakarta \\ ${ }^{1,2}$ J1. Slamet Riyadi No. 361 Windan, Makamhaji, Kartasura, Sukoharjo, Indonesia \\ ${ }^{1}$ hariez.pujianto@gmail.com, ${ }^{2}$ elfathiey@gmail.com
}

\begin{abstract}
The UNS Hospital E-Patient Application for Online Registration of UNS Hospital Patients is an application belonging to the UNS Hospital that can be used by old UNS Hospital patients to register for polyclinic visits online. Analysis of the "E-Patient Hospital UNS" application system from the results of an interview with the Head of the UNS Hospital Electronic Data Installation, which is the person in charge of the management of the application. The author also uses the results of the application user survey from January 1, 2020 s.d. November 27, 2020 to determine the level of customer satisfaction in conducting system analysis. The purpose of this system analysis is to find out how much the function or usefulness of this application system is to unravel or minimize the problems that become obstacles related to registration of polyclinic patient visits at UNS Hospital.
\end{abstract}

Keywords: E-patient, uns, registration, online, android

\section{INTRODUCTION}

In the current era, there are a lot of people / patients who carry out visits or examinations at the hospital polyclinic every day. This is also accompanied by problems that arise, especially the problem of patient registration related to the number of quotas that can be served by the hospital per day. Lots of patients who complain of problems enrolling polyclinics or outpatient services in various hospitals. Things that usually become obstacles or problems for patients include : Must arrive as early as possible to register at the hospital / on-site registration, The patient has arrived at the hospital, it turns out that the quota for that day is full, There is an accumulation of registration queues at the hospital. In addition, the hospital itself cannot predict the number of patients per day. This is due to the absence of data on the number of patients who will visit the polyclinic. The purpose of the analysis of the "E-Patient Hospital UNS" application system for the Online Registration of UNS Hospital Patients is to determine the effectiveness of the "E-Patient UNS Hospital" application for registering visits to the polyclinic of old UNS Hospital patients.

\section{RESEARCH METHODS}

This study used two methods, namely interviews, functional tests, and review of the results of the user satisfaction survey of the application "E-Patient UNS Hospital".

\subsection{Data Collection Methods}

The following data collection methods are as follows:

1. Interview

Interviews were conducted with the Head of the UNS

Hospital Electronic Data Installation who is also the program administrator of the "E-Patient Hospital UNS" application.

2. Observation

This method the authors try to use or operate the application "E-Patient RS UNS" to find out the program flow, features, and how this application works.

3. Literature study

This application has provided a customer satisfaction survey feature and the survey result data is stored on the server data in an .xls format file. From this data, the authors took data sampling from January 1, 2020 s.d. November 27, 2020.

\subsection{Systems Development Method}

Methods in system development are as follows: System Planning : Planning in making the application "E-Patient UNS Hospital" is based on the existence of: The need for fast and easy health services, Online registration is recommended in SNARS (National Hospital Accreditation Standards) by KARS (Hospital Accreditation Commission), Accomodating requests from patients, Most Indonesians currently use Android smartphones in their daily life, System Analysis, The "E-Patient UNS Hospital" application will process the registration of old patients or patients who already have medical records at UNS Hospital. As for new patients, they must register offline at UNS Hospital.

After the patient has logged in and selects the List menu, the system will provide a check date option to be selected first. After selecting the check-up date, the patient can choose the desired poly. Furthermore, the system will adjust the availability of doctors that can be selected by the patient on that date. This is because not all doctors have scheduled polyclinic services every day. The next step, the patient chooses the payment method that will be used. System Design : The "E-Patient Hospital UNS" application is designed or built based on Android which is a platform that is currently widely used by most people today. Its appearance and features are also designed to be as simple as possible so that it is easier for people to understand and use the service. System Implementation : UNS Hospital patients who will use this application are very easy. What is certain is that the patient must have an android cellphone and install the "E-Patient Hospital UNS" application, then the patient just needs to log in using a personal RM (medical record) number. To install the "E-Patient Hospital UNS" application, users can download it on the Google Play Store service on their Android phone. Apart from going through the Google Play Store, users can also download applications through the website page http://rs.uns.ac.id/unduh/, System Testing : System testing is carried out by direct practice using or operating the "E-Patient Hospital UNS" application. This stage begins with the installation of the "E-Patient Hospital UNS" application, opening and testing the available service features. 
International Journal of Computer and Information System (IJCIS)

Peer Reviewed - International Journal

Vol : Vol. 02, Issue 01, February 2021

e-ISSN : 2745-9659

https://ijcis.net/index.php/ijcis/index

System testing is also carried out using questionnaire results from service users or patients who use this application within a certain period.

The definition of a management information system according to Moekijat (2005) is a network of data processing procedures designed and developed within an organization, with the intention of providing data / information to management / leadership at any time needed, both internal and external data / information, for the basis of decision making in carrying out managerial functions in order to achieve organizational goals.

Decision Support System or Decision Support System, which we briefly refer to in this thesis, is generally defined as a system capable of providing both problem-solving and communication skills for semistructured problems. In particular, DSS is defined as a system that supports the work of a manager or a group of managers in solving semistructured problems by providing information or suggestions leading to certain decisions.

Android is an operating system on mobile phones that is open and based on the Linux operating system. Android provides an open platform for developers to create their own applications to be used for a variety of mobile devices. The choice of an application is built based on android because the android operating system has several advantages when compared to other operating systems, including : Multitasking, Ease of Notification, Easy access to thousands of applications via the Google Android App Market, Mobile options.

The application "E-Patient at UNS Hospital" is an application designed for the online registration process for old patients at the polyclinic. With this application, patients do not have to come to UNS Hospital to register a schedule for the UNS Hospital polyclinic visit. Online registration can be done a maximum of 2 (two) days before the patient's preferred visit schedule. In addition, patients can also find out the desired polyclinic quota from this application. So that if the quota on the desired day is full, the patient can register the schedule on another day.

The application "E-Patient at UNS Hospital" can be downloaded from the Google Play Android service or it can also be downloaded through the official website of the UNS Hospital, namely http://rs.uns.ac.id. To be able to use this application service, patients must $\log$ in by entering their RM (Medical Record) number and date of birth of the patient. In other words, the patient must have been treated or used health services at the UNS Hospital before, so that the patient is registered and has a RM (Medical Record) number at the UNS Hospital.

Android Studio is the official Integrated Development Environment (IDE) for Android application development, which is based on IntelliJ IDEA. Apart from being Intellij's powerful code editor and developer tools, Android Studio offers many features that increase your productivity in building Android apps. SQL is a standard ANSI (American National Standards Institute) programming language for manipulating databases. SQL works with a variety of database applications, such as MS Access, MS SQL Server, Oracle.

\section{RESULT AND ANALYSIS}

In the discussion, discussing the results of research in the form of system design as a whole are as follows:

\subsection{Computerized System Analysis}

Before the "E-Patient Hospital UNS" application, polyclinic patient registration only relied on an offline registration system. Where registration is done manually and served in one place, namely the UNS Hospital. In this system, many problems arise, which are detrimental to patients and hospitals. Lots of complaints from old patients who have been routinely checked at UNS Hospital. One of the problems that patients often experience is where the patient has come to the UNS Hospital and queued to get a registration number, but the patient quota has run out. This is certainly very disappointing and detrimental to the patient.

\subsection{System Design}

The application "E-Patient RS UNS" was built using the Android Studio 3.1.2 program with the programming language used is the Java Programming Language (Android). Eclipse Software is also used to create android applications, create a user interface using $\mathrm{xml}$ as a layout and then enter commands to call the user interface that has been created with a program in the Java programming language. Android Development Tools (ADT) are also needed as a plugin used by Android Studio software designed for Android application development. ADT allows android studio to be used in creating new android applications, creating user interfaces, adding components based on the android API framework, debugging applications, and packaging Android applications. This section contains an explanation of system design for building management information system applications.

\section{Context Diagram}

The context diagram (CD) for the online attendance system using application is as follows :

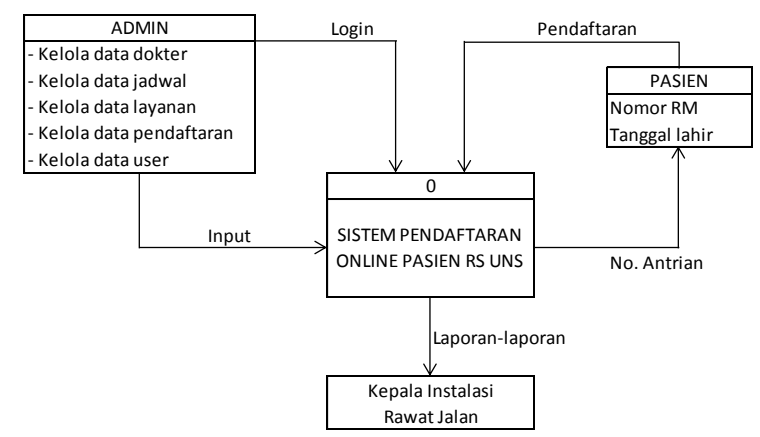

Figure 1. Context Diagram

\section{HIPO}

HIPO (Hierarchy plus Input-Process-Output) is a design tool and documentation technique in the system development cycle. The following is the HIPO of an online attendance information system using the application. 
International Journal of Computer and Information System (IJCIS)

Peer Reviewed - International Journal

Vol : Vol. 02, Issue 01, February 2021

e-ISSN : 2745-9659

https://ijcis.net/index.php/ijcis/index

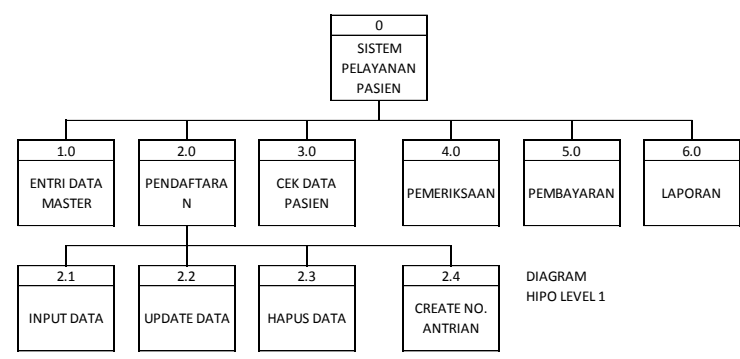

Figure 2. HIPO

3. DAD (Data Flow Diagram)

Data Flow Diagram (DAD) is a diagram that uses notation notation to describe the flow of system data, the use of which can help to understand a system in a clear and structured manner. The following is DAD level 0 from an online attendance information system using the GreatDay HR application which is an explanation of context diagrams and HIPO.

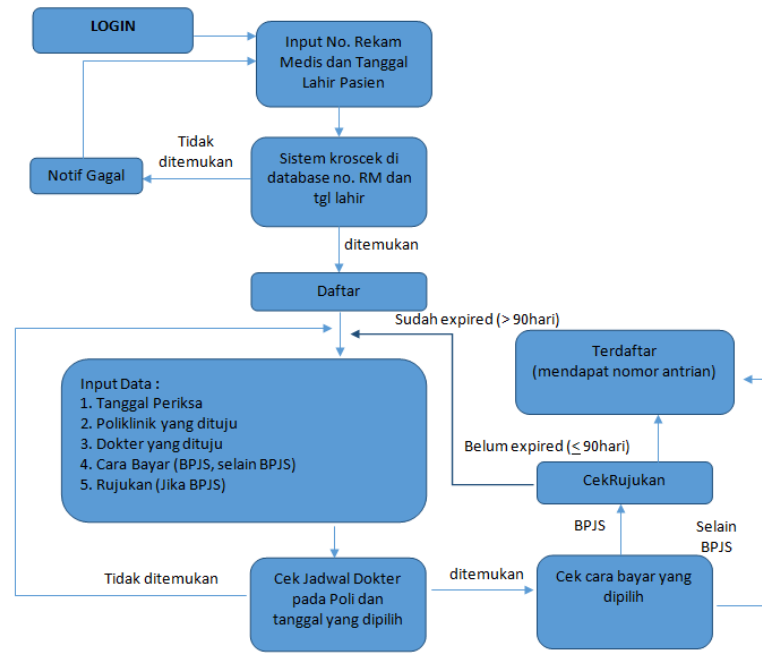

Figure 3. DAD

\subsection{System Implementation} Store:

How to download and install from the Google Play
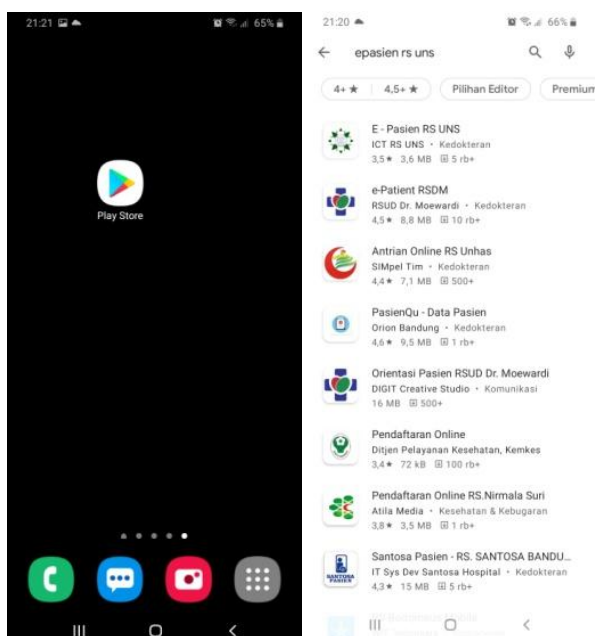

Figure 4. Home view

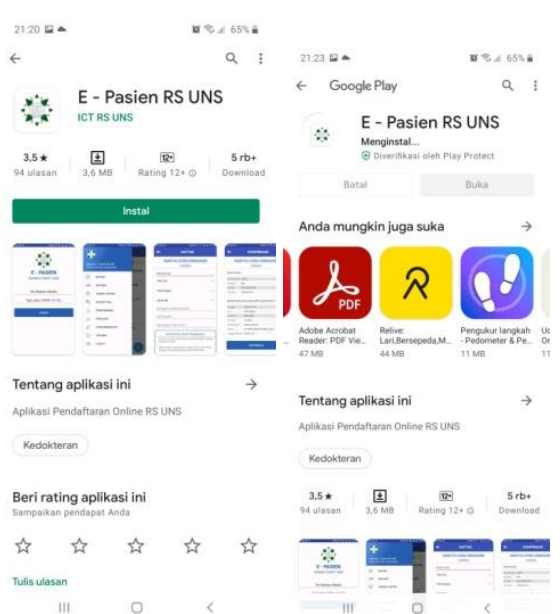

Figure 5. Instalation
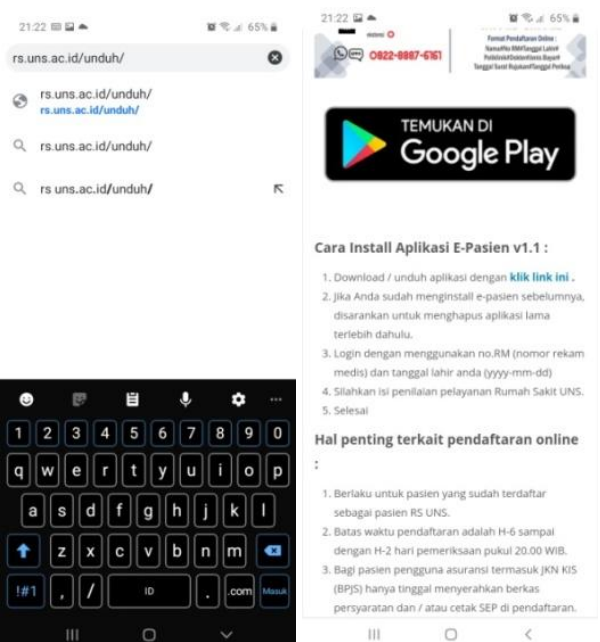

Figure 6. Application "E-Patient UNS Hospital"

\subsection{System Testing}

Testing is done by two methods, namely testing the functionality and testing the questionnaire.

3.4.1. Functionality Testing

System testing is carried out after the installation process of the "E-Patient Hospital UNS" application is complete and logged in using the patient's RM number and date of birth. The trial was carried out by trying to register the Internal Medicine Polyclinic patient, selecting the day, and the desired doctor.

\subsubsection{Quizoner Testing}

The following is the questionnaire data for the user satisfaction of the application "E-Patient UNS Hospital" on January 1 s.d. November 30, 2020 with a total of 2345 respondents.

Table 1. Testing System

\begin{tabular}{lrr}
\multicolumn{1}{c}{ Tanggapan } & \multicolumn{1}{c}{ Jumlah } & \multicolumn{1}{c}{ Prosentase } \\
\hline Puas & 1953 & $83,28 \%$ \\
\hline Kurang Puas & 180 & $7,68 \%$ \\
\hline Tidak Mengisi & 212 & $9,04 \%$ \\
\hline \multicolumn{1}{c}{ Total } & 2345 & $100 \%$ \\
\hline
\end{tabular}


International Journal of Computer and Information System (IJCIS)

Peer Reviewed - International Journal

Vol : Vol. 02, Issue 01, February 2021

e-ISSN : 2745-9659

https://ijcis.net/index.php/ijcis/index

\subsubsection{SWOT analysis}

At this time it can be said that the application "E-Patient RS UNS" is able to answer and solve problems that occur in offline registration or on the old system. With patient characteristics, polyclinic services, types of funding, and doctors currently available can be accommodated by the application "E-Patient UNS Hospital".

A weakness of this system is when there is a doctor's schedule change because the doctor is unable to attend or due to something sudden, then this becomes an obstacle that must be resolved by IT administrators. The administrator must change the doctor's schedule on that day and automatically patients who have already registered will be replaced by another doctor on the check-up date.

\section{CONCLUSION}

From the analysis and testing that has been done, it can be concluded that the use of the "E-Patient RS UNS" application for online registration of UNS Hospital patients is a solution to the problem of the offline patient registration system. This application provides effectiveness and efficiency for patients and hospitals. The thing that the authors suggest, especially for the developer of the application "E-Patient RS UNS" is to be able to develop the application not only for polyclinic patient registration. Perhaps it could be developed for elective surgical patient registration or planned surgery and medical check-up services.

\section{REFERENCES}

[1] Moekijat.2005. Introduction to Management Information Systems. Bandung: CV. Mandar Forward

[2] Turban, Efraim, 1930-.1999. Information technology for management: making connections for strategic advantage. New York: John Wiley \& Sons

[3] Safaat H, Nasruddin. Programming of Android-Based Smartphone and Tablet PC Mobile Applications. From https://elib.unikom.ac.id/files/disk1/578/jbptunikompp-gdlaamsitifat-28858-6-unikom_a-i.pdf

[4] Hermawan, Julius. 2005. Building a Decision Support System. Yogyakarta: Andi.

[5] Grace. 2007. Introduction of SQL. From http://rahmat.polinpdg.ac.id/content/view/62/64/. $10 \quad$ June 2010.

[6] Muqorobin, M., \& Rais, N. A. R. (2020). Analysis of the Role of Information Systems Technology in Lecture Learning during the Corona Virus Pandemic. International Journal of Computer and Information System (IJCIS), 1(2).

[7] Muqorobin, M., Kusrini, K., Rokhmah, S., \& Muslihah, I. (2020). Estimation System For Late Payment Of School Tuition Fees. International Journal of Computer and Information System (IJCIS), 1(1).

[8] Solihin, Ahmad, MySQL 5 From Beginner to Advanced, Achmatim. net. Jakarta. https://www.firebase.com/features.html, accessed September 26, 2015.
[9] Muqorobin, M., Rokhmah, S., Muslihah, I., \& Rais, N. A. R. (2020). Classification of Community Complaints Against Public Services on Twitter. International Journal of Computer and Information System (IJCIS), 1(1).

[10] Muqorobin, M., \& Rais, N. A. R. (2020, November). ANALISIS PERAN TEKNOLOGI SISTEM INFORMASI DALAM PEMBELAJARAN KULIAH DIMASA PANDEMI VIRUS CORONA. In Prosiding Seminar Nasional \& Call for Paper STIE AAS (pp. 157-168).

[11] Utomo, I. C., Rokhmah, S., \& Muslihah, I. (2020). Web Based Distribution of Zakat, Infaq, and shodaqoh (Case Study Of Surakarta City Region). International Journal of Computer and Information System (IJCIS), 1(1).

[12] K. Kusrini, E. T. Luthfi, M. Muqorobin and R. W. Abdullah, "Comparison of Naive Bayes and K-NN Method on Tuition Fee Payment Overdue Prediction," 2019 4th International Conference on Information Technology, Information Systems and Electrical Engineering (ICITISEE), Yogyakarta, Indonesia, 2019, pp. 125-130, doi: 10.1109/ICITISEE48480.2019.9003782.

[13] Muqorobin, M., Hisyam, Z., Mashuri, M., Hanafi, H., \& Setiyantara, Y. (2019). Implementasi Network Intrusion Detection System (NIDS) Dalam Sistem Keamanan Open Cloud Computing. Majalah Ilmiah Bahari Jogja, 17(2), 1-9.

[14] Muqorobin, M., Apriliyani, A., \& Kusrini, K. (2019). Sistem Pendukung Keputusan Penerimaan Beasiswa dengan Metode SAW. Respati, 14(1).

[15] Abdullah, Robi W., et al. "Keamanan Basis Data pada Perancangan Sistem Kepakaran Prestasi Sman Dikota Surakarta." Creative Communication and Innovative Technology Journal, vol. 12, no. 1, 2019, pp. 13-21.

[16] Saputra, R., \& Rais, N. A. R. (2020). Online Sales System Analysis of PT. Nutrifood Indonesia through the distributor CV. Trio Sukses Mandiri Solo With Nutrimart Home Delivery (NHD) Application. International Journal of Computer and Information System (IJCIS), 1(2).

[17] Muslihah, I., Muqorobin, M., Rokhmah, S., \& Rais, N. A. R. (2020). Texture Characteristic of Local Binary Pattern on Face Recognition with PROBABILISTIC LINEAR DISCRIMINANT ANALYSIS. International Journal of Computer and Information System (IJCIS), 1(1).

[18] Hikmah, I. N., \& Muqorobin, M. (2020). Employee Payroll Information System On Company Web-Based Consultant Engineering Services. International Journal of Computer and Information System (IJCIS), 1(2).

[19] Nastura, S. A., \& Muqorobin, M. (2020). Transaction Processing System Analysis Using The Distribution Management System (DMS) Nexsoft Distribution 6 (ND6). International Journal of Computer and Information System (IJCIS), 1(2).

[20] Muqorobin, M., \& Rais, N. A. R. (2020). Analysis of the Role of Information Systems Technology in Lecture Learning during the Corona Virus Pandemic. International Journal of Computer and Information System (IJCIS), 1(2). 